\title{
Mammary Gland Reprogramming: Metalloproteinases Couple Form with Function
}

\author{
Rama Khokha ${ }^{1}$ and Zena Werb ${ }^{2}$ \\ ${ }^{1}$ Ontario Cancer Institute/University Health Network, University of Toronto, Toronto, \\ Ontario, M5G 2M9, Canada \\ ${ }^{2}$ Department of Anatomy and Program in Developmental Biology, School of Medicine, \\ University of California at San Francisco, San Francisco, California 94143-0452 \\ Correspondence: rkhokha@uhnres.utoronto.ca; zena.werb@ucsf.edu
}

\begin{abstract}
The adult mammary structure provides for the rapid growth, development, and immunological protection of the live-born young of mammals through its production of milk. The dynamic remodeling of the branched epithelial structure of the mammary gland in response to physiological stimuli that allow its programmed branching morphogenesis at puberty, cyclical turnover during the reproductive cycle, differentiation into a secretory organ at parturition, postlactational involution, and ultimately, regression with age is critical for these processes. Extracellular metalloproteinases are essential for the remodeling programs that operate in the tissue microenvironment at the interface of the epithelium and the stroma, coupling form with function. Deregulated proteolytic activity drives the transition of a physiological mammary microenvironment into a tumor microenvironment, facilitating malignant transformation.
\end{abstract}

M

ilk production is an evolutionary survival strategy that allows the rapid growth and development of live-born young, as well as being a defining trait of mammals. Milk production at parturition and not at other times conserves valuable energy resources of the mother. It also provides immunological protection to the offspring. Thus, the response of the adult mammary structure to changes in systemic hormones as well as locally derived factors is to expand the ductal network into a milkproducing gland rapidly and to tear it down again when its function is no longer required. The origin of the mammary gland during evolution including its link with the immune system has inspired considerable interest but remains speculative (Oftedal 2002; Vorbach et al. 2006; Widelitz et al. 2007; McClellan et al. 2008). Although the branched epithelial structure of the mammary gland varies in composition and complexity among mammals, the alveolar acinus, its cellular secretory unit, and the tubular ducts, which channel milk for delivery through the teat, have been conserved in mammals.

Editors: Mina J. Bissell, Kornelia Polyak, and Jeffrey Rosen

Additional Perspectives on The Mammary Gland as an Experimental Model available at www.cshperspectives.org

Copyright (C) 2011 Cold Spring Harbor Laboratory Press; all rights reserved; doi: 10.1101/cshperspect.a004333

Cite this article as Cold Spring Harb Perspect Biol 2011;3:a004333 
The concept of form and function first arose from the study of mammary epithelial cells and has become a cornerstone in biology, because it applies universally to other parenchymal units (Lee et al. 1984). Here, epithelial cells retain apical-basal polarity and shape by establishing physical contacts with the structural matrix and neighboring cells, and build an adequate form to enable their function of milk production in response to appropriate stimuli (Boudreau and Bissell 1998). The mammary gland encounters constant physiological demands during the female lifespan. To maintain its function, it must repeatedly reacquire its fundamental form with the preservation of cell types, ratios, differentiation state, and matrix integrity. This requires remodeling programs that initially allow development of the mammary gland at puberty, cyclical turnover during the reproductive cycle, differentiation into a secretory organ at parturition, postlactational involution, and ultimately, regression with age. In this article, we describe the essential features of remodeling programs that generally operate at the parenchymal-stromal interface in the mammary tissue microenvironment, and highlight the critical role of extracellular proteolysis in coupling form with function. We also discuss how deregulated protease activity facilitates the transition of a physiological mammary microenvironment into a tumor microenvironment.

Our understanding of the mammary gland has been enriched by the use of the mouse as an experimental system, and, thus, observations from murine genetic models, loss- and gainof-function studies, as well as transplantation assays form the basis of this article. Although the mouse has become an integral part of investigations, there are notable differences between human and murine mammary biology (Cardiff and Wellings 1999). The mammary epithelial ductal system in humans differs considerably with respect to its branching pattern, the stromal, adipocyte, and extracellular matrix (ECM) content, as well as the hormonal triggers that provide the mammotrophic stimuli. Therefore species-specific differences must be considered while making generalizations for the mammary gland.

\section{DYNAMIC STAGES OF THE MAMMARY GLAND}

A rudimentary ductal tree forms during embryogenesis, but the most remarkable and dynamic morphological changes of the mammary gland occur from puberty to menopause. The discrete stages of the mammary gland are shown in Figure 1. In the mouse, the mammary anlagen become apparent as disk-shaped placodes in the ectoderm at mid-gestation (embryonic day 10.5). Surrounded by a distinct mesenchyme, the placode sinks deeper into the dermis and invaginates to form a lumen, in response to a number of locally secreted molecules (Robinson 2007; Watson and Khaled 2008). Interestingly, each of the five pairs of glands that develop in the mouse requires different sets of cues, calling for distinct, but overlapping sets of morphogens. For example, only the abdominal mammary grand (\#4) develops in the absence of fibroblast growth factor- 10 (FGF10). Mammary mesenchyme is induced by the mammary epithelial signal and expresses steroid hormone receptors for estrogen and androgen, as well as specific matrix proteins. At puberty, branching morphogenesis is triggered by the mammotrophic signals provided by the hypothalamic-ovarian-pituitary axis (Sternlicht et al. 2006). Following the rules common to many organs that display branched tubular structures (Affolter et al. 2003), the mammary ductal tree elongates as epithelial cells grow and invade the adipocyte-rich stroma led by the terminal end buds (TEB), which are highly motile structures located at the forefront of ducts (Hinck and Silberstein 2005). Stimulation by growth hormone $(\mathrm{GH})$ induces stromal insulin-like growth factor 1 (IGFI) whereas ovarian estrogens stimulate release of epithelial amphiregulin to mediate stromal-epithelial cross talk during pubertal mammary development (Sternlicht 2006; Sternlicht et al. 2006). The bulbous TEBs undergo repeated dichotomous branching to form adequately spaced primary ducts with lumens, whereas concomitant secondary and tertiary side branching occurs by lateral bud sprouting (Wiseman and Werb 2002; Lu et al. 2006; Lu and Werb 2008). 


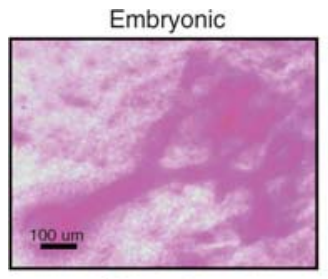

Pro-estrus

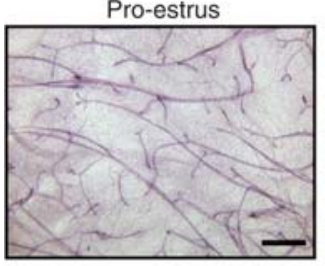

Gestation

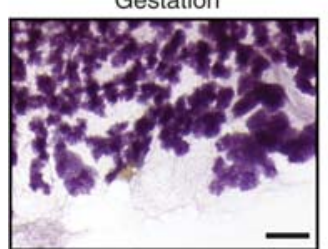

Prepubescent

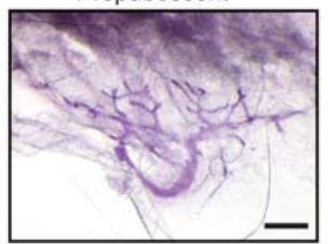

Estrus

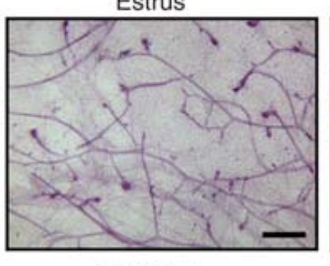

Lactation

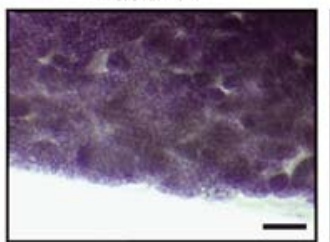

Pubertal

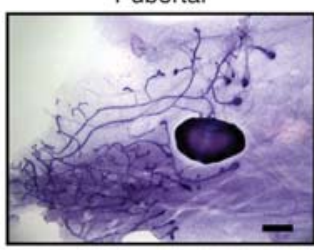

Met-estrus

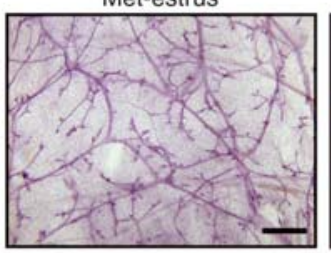

Involution

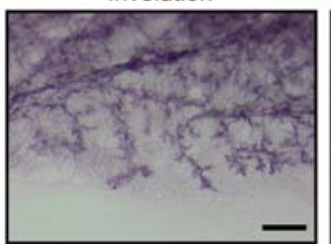

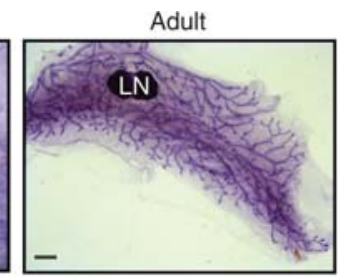

Di-estrus

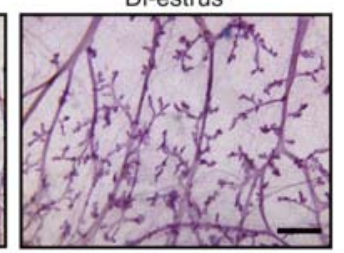

Aged

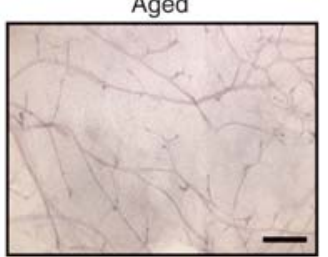

Figure 1. Distinct stages of mammary gland remodeling. A series of murine mammary whole mounts illustrating distinct mammary morphology during the indicated stages of development from embryonic through to adult, the prenatal rudimentary ductal tree (embryonic day 18-5), postnatal prepubescent mammary gland (2-wk old), rapidly elongating pubertal mammary gland with bulbous TEBs (5-wk old), and the fully developed adult gland (10-wk old) that has reached the limits of the fat pad. Mammary glands at specific phases of the estrus cycle ( proestrus, estrus, metestrus, diestrus) showing lobuloalveologenesis at diestrus. The major reproductive phases that involve extensive remodeling are gestation (day 18.5 gestation), which shows extensive lobuloalveolar differentiation; lactation, which highlights a functionally differentiated gland; postlactational involution (day 8 postlactation), which shows the loss of secretory epithelium; and finally, 20-mo old mice, which have ceased the reproductive cycle show a dormant ductal tree. Size bar $=100 \mu \mathrm{m}$ (Embryonic); $1 \mathrm{~mm}$ (Pubertal and Adult); $50 \mu \mathrm{m}$ in all other panels

The ductal tree ceases forward growth when it approaches the distal limits of the fat pad, dictated in part by transforming growth factor beta (TGF $\beta$ ) signaling (Sternlicht 2006). The mechanistic processes underlying branching morphogenesis are dynamic and form the subject of many comprehensive reviews that draw attention to their individual complex nature.

The branched structure of the mammary gland is well suited for maximizing its cellular surface area as it structurally and functionally adapts to the assigned physiological demand. In the adult female, the mammary gland undergoes repeated cyclical turnover during each reproductive cycle, systematically displaying lobuloalveologenesis during the murine diestrus phase (Robinson et al. 1995; Fata et al. 2001a), which parallels the luteal phase in humans. Increased mammographic density has been reported during this phase of the reproductive cycle in women (Ursin et al. 2001). In mice, this changing morphology is accompanied by rounds of cell proliferation as well as cell death that peak at diestrus. Thus, the mammary ductal tree matures gaining structural complexity by further secondary and tertiary branching. This lateral branching requires more extensive remodeling because it must breach an additional structural barrier.

Progesterone secretion rises in response to the postcoitum maintenance of the corpus luteum, and this function is taken over by the placenta as pregnancy establishes. Progesterone, 
together with pituitary-derived prolactin, provides key signals for orchestrating mammary epithelial differentiation during pregnancy (Brisken et al. 1999; Oakes et al. 2008). Extensive mammary epithelial proliferation ensues, resulting in $\sim 100$-fold increase in the cell number, accompanied by cellular differentiation, polarization and development of secretory epithelium during a relatively short period of 19 days of gestation in the mouse. The ratio of adipocytes to epithelia decreases to facilitate parenchymal expansion during this phase. A complex milieu of hormones marked by a drop in progesterone activates epithelial changes leading to lactation, which is typically maintained by the suckling response of the newborn (Neville et al. 2002; Pang and Hartmann 2007). Postlactation mammary involution, studied after natural or forced weaning, involves rapid regression of the differentiated gland and depends on programmed cell death pathways that eliminate up to $50 \%-80 \%$ of the secretory epithelium within 1 wk of weaning (Walker et al. 1989). Two phases of involution have been described, the first is a potentially reversible period initiated by mechanical triggers associated with milk-stasis, and the second is a programmed deconstruction of the lobuloalveolar acini and the supporting structural ECM (Lund et al. 1996; Alexander et al. 2001; Watson 2006). The latter phase is dominated by the involvement of extracellular proteases with concomitant reconstitution of the adipocyte compartment. The secretory alveoli collapse, forming epithelial cords, eventually returning the glandular structure to a pregestation phenotype that resembles the virgin mammary gland. Along with the classical apoptosis pathways (Watson 2006), phagocytosis by cells of the monocyte lineage (O'Brien and Schedin 2009), as well as the more recently discovered epithelial cell autophagy (Atabai et al. 2007; Monks et al. 2008; Zarzynska and Motyl 2008), contribute to involution. Distinct from postlactation involution is the irreversible process of lobular involution that is associated with age-related, gradual loss of breast epithelial tissue (Radisky and Hartmann 2009). In humans, this regression begins at variable ages in women, early or during perimenopause, and leads to decreased size and complexity of the mammary ductal tree.

The substantial plasticity of the ductal network is thus evident throughout the female lifespan. Plasticity of the mammary gland is not merely biologically intriguing; it is intimately tied to breast cancer as documented by the vast but complex epidemiology literature. Briefly, a higher number of menstrual cycles, because of early menarche or late menopause correlate with an increased risk of developing breast cancer (Kelsey et al. 1993; Veronesi et al. 2005). Mammary gland regression after pregnancy is implicated in tumor promotion because poorer prognosis is seen in a subset of patients diagnosed within 5 years of pregnancy (O'Brien and Schedin 2009). Conversely, parity, with a limited number of pregnancies, and breast feeding are considered preventative against breast cancer when compared with nulliparous women or those who never breastfed (Akbari et al. 2010). The more recent literature suggests that premenopausal women displaying partial or complete lobular involution have a reduced breast cancer risk (Radisky and Hartmann 2009). Distinct from the above examples is the well established fact that women with higher mammographic density, which is attributable to a greater cellularity and ECM content, have a significantly higher lifetime risk of developing breast cancer (Boyd et al. 2009). Overall, the complexity of ductal cellular structures where breast cancer originates, as well as continuing cycles of turnover, impact women's susceptibility to developing breast cancer.

\section{CELLULAR COMPOSITION AND STRUCTURAL COMPONENTS OF THE MAMMARY GLAND}

Mammary epithelial and stromal compartments each contain multiple cell types, which are illustrated in the cross sections of the mammary ducts and TEB shown in Figure 2. The ducts, ductules and lobular structures make up the functional units of the mammary gland and are lined with two types of epithelium. The cuboidal luminal epithelial cells produce 

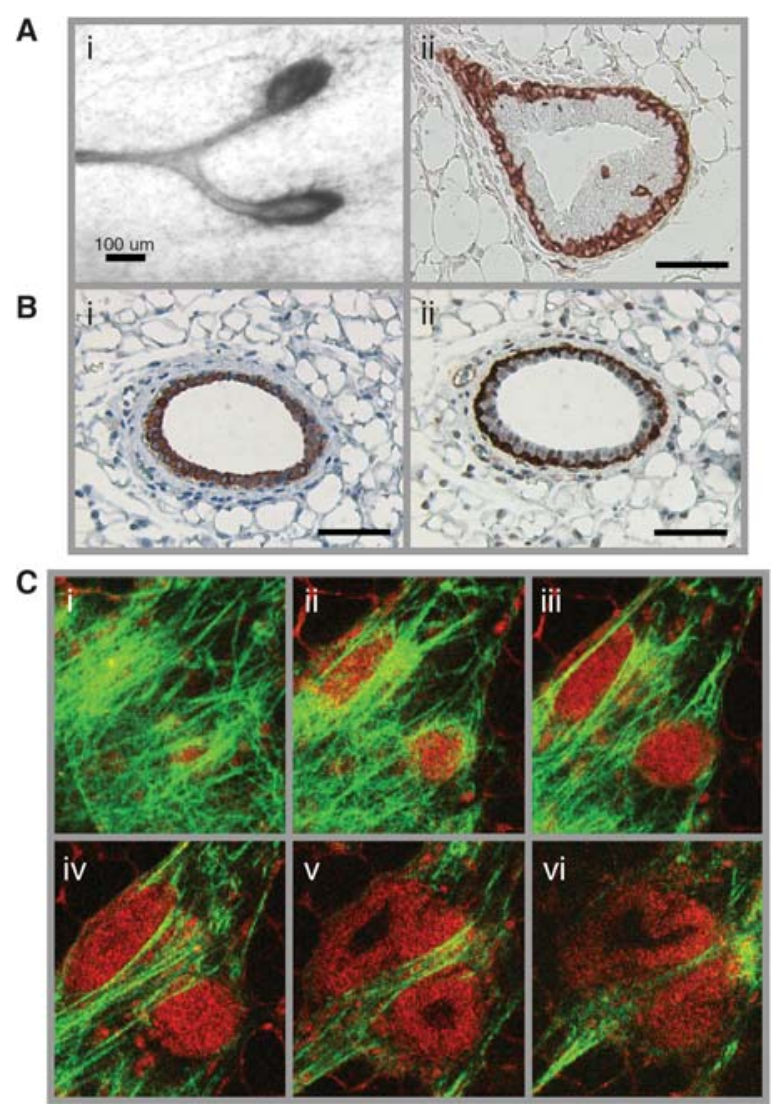

Figure 2. Composition of the mammary gland. (A) A mammary epithelial duct showing TEBs at the distal tips (i), and smooth muscle actin staining, which marks the outer layer of cap cells (ii). The multicellularity of TEB can be seen as an outer layer of cap cells and an inner core of body cells. (B) The bilayered mammary duct showing an inner layer of cytokeratin 18-stained luminal epithelial cells (i), and an outer layer of smooth muscle actinstained myoepithelial/basal cells (ii). Periductal fibroblasts can be seen in the vicinity of a bilayered duct, which is in turn surrounded by distal fibroblasts and adipocytes in these cross sections. (C) Serial multiphoton optical section images demonstrating the intimate contact between native collagen type I fiber bundles (detected by second harmonic generation, green) and autofluorescence (red) of cells comprising TEBs (i-vi). Individual image slices of an isolated $35 \mathrm{~d}$ old mammary gland were selected out of a 3D image volume generated by multiphoton laser scanning microscopy, revealing (i-iii) collagen surrounding the TEB surface, and (ii-iv) progressive slicing through to the cap and body cells of the TEB, with the lumen becoming apparent in deeper slices (v, vi). Size bar $=100 \mu \mathrm{m}$ (Ai); $50 \mu \mathrm{m}$ (Aii, Bi-ii).

milk on differentiation, and these are in intimate contact with flattened myoepithelial cells, which are oriented at the basal surface in parallel with the basement membrane. The actin microfilaments of myoepithelial cells provide contractility to the luminal and acinar structures to facilitate milk ejection. Mammary gland stem cells have been hypothesized to reside in specialized niche(s) within the basal myoepithelial layer, distributed along the ducts. This is rooted in the observation that mammary epithelium from any region of the ductal tree can reconstitute a functional mammary gland following transplantation into a cleared fat pad (Brisken and Duss 2007). The entire epithelial ductal tree is encased in a network of connective tissue and histologically complex stroma constituted of fibroblasts, adipocytes 
and endothelial cells. Avariety of bone marrowderived or resident immune cells also populate the mammary gland in varying abundance. Some of these innate and acquired immune cells increase during periods of active mammary gland remodeling (Atabai et al. 2007). The clubshaped TEBs are only seen at puberty and contain a heterogeneous multilayered cell population, with an outer layer of basal progenitor cells termed as cap cells, and an inner core of luminal progenitor cells called body cells. TEBs are both motile and mitotically active and are considered to be prime targets for carcinogenic insult (Anderson and Beattie 1992).

Mammary epithelial cell-cell contact is built through desmosomes and cadherin-mediated adherens junctions, whereas other classes of proteins generate tight junctions and gap junctions or determine the apicobasal polarity. A physical boundary created by the basement membrane exists around every epithelial unit. The repertoire of ECM proteins found in the mammary gland changes in composition, assembly and degradation in a stage-specific manner (Fata et al. 2004; Xu et al. 2009). As such, ECM extracted from defined remodeling stages of the rat mammary gland induces different effects in 3-dimensional mammary epithelial cultures on glandular development, morphogenesis, reorganization or cell death, that are reflective of the original gland (Schedin et al. 2004). The type of ECM molecules found at the tip of TEBs differs from those that flank the ducts. For instance, collagen type IV and laminins are concentrated near TEBs and around the alveoli, whereas fibrillar collagen I is predominantly localized along the ducts (Keely et al. 1995). Interestingly, whereas forward TEB growth depends on epithelial cell proliferation and ECM breakdown at the tip, deposition of ECM at the tip is required to create an impediment and serve as a guide for TEB bifurcation. Additionally, ECM imposed constriction per se maintains its bulbous nature (Hinck and Silberstein 2005). The ECM proteins including collagens, laminins, and fibronectin interact with their respective cell surface receptors, the integrin heterodimers (Fata et al. 2004; Hinck and Silberstein 2005), as well as with nonintegrin ECM receptors including dystroglycans, syndecans, and discoidin domain receptors (Fata et al. 2004).

Dynamic reciprocity is the term for extra/ intracellular communication via the ECM/cell cytoskeleton, with this communication becoming instrumental in the propagation of biochemical signals arising from the activated cell surface receptors and also for sensing mechanical cues and stresses (Xu et al. 2009). How mechanotransduction affects mammary form and function and alters mammary tumorigenesis has grown into a new field (Butcher et al. 2009). Overall, there is a molecular continuum from the ECM to the epithelial cell surface and on to the cell nucleus. Mammary gland remodeling requires deconstruction and reassembly of multiple intricate structures throughout the tissue calling for precise regulation of numerous processes across epithelial-stromal-adipocyte compartments.

\section{THE MAMMARY REMODELING PROGRAM}

The remodeling process is a means of tissue reprogramming designed to conserve its physiological function. It can be viewed as a set of hierarchical platforms beginning with systemic mammogens that oversee and integrate female reproductive development and function with that of the mammary tissue. These mammogens induce mitogens to initiate growth, epithelial ductal branching and differentiation, and inhibitors to terminate ductal growth or balance proliferation with apoptosis. A program of ECM modifiers is necessary to tailor the structural support of the mammary tissue, with a parallel system to alter cell-cell adhesion. The overall tissue regenerative capacity also demands mammary stem cell recruitment as well as immune cell function.

\section{Systemic Mammogens}

Mammary morphogenesis depends on the hypothalamic-pituitary-ovarian axis, which involves cooperation of gonadotropin-releasing hormone produced by hypothalamus, luteinizing hormone and follicle-stimulating hormone from the anterior pituitary, as well as estrogen and 
progesterone secreted by the ovary. A series of studies involving ovariectomy and hypophysectomy, as well as mammary transplants in mice lacking ovarian hormone or growth factor receptors, have established $\mathrm{GH}$ as the master regulator of this process (Sternlicht 2006). It is secreted by the pituitary and leads to the production of ovarian-derived 17- $\beta$ estradiol and progesterone. $\mathrm{GH}$ and $17-\beta$ estradiol then involve locally produced IGF1 as a stromal intermediary in exerting their effects on epithelial cells (Kleinberg et al. 2000). GH binds its receptor on stromal cells to induce IGF1 expression, which in turn interacts with its receptor on epithelial cells. The understanding of estrogen receptor localization has shifted over the years to show its requirement in the epithelium for normal mammary development (Bonnette and Hadsell 2001; Richards et al. 2004; Mallepell et al. 2006; Sternlicht et al. 2006), and that it affects mammary development in a noncell autonomous manner. 17- $\beta$ estradiol induces the expression of epidermal growth factor receptor (EGFR) ligands, which together with $\mathrm{GH}$-induced IGF1 provides a synergistic effect on TEBs. Among the seven EGFR ligands, amphiregulin is critical for ductal morphogenesis (Sebastian et al. 1998; Luetteke et al. 1999). In contrast to estrogen, progesterone is redundant for pubertal ductal development, but is required for tertiary side branching and lobuloalveologenesis, where it acts synergistically with IGF1 (Brisken et al. 1998; Ruan et al. 2005). 17- $\beta$ estradiol also induces progesterone receptor (PR) expression and, of its two-receptor isoforms, the $\mathrm{B}$ isoform has been shown to be essential and sufficient for tertiary branching (Humphreys et al. 1997; Brisken et al. 1998). Interestingly, PR may be differentially required in the epithelial and stromal compartments for lobuloalveolar development and tertiary branching. In the reproductive cycle, maximal serum progesterone levels at the diestrus phase of the estrus cycle positively correlate with tertiary branching, lobuloalveologenesis, alveolar proliferation, as well as apoptosis in the mammary gland of an adult female (Fata et al. 2001a). During pregnancy, prolactin and progesterone are critical mammogens for tertiary branching and secretory differentiation of the alveolar compartment. Mice lacking either prolactin or its receptor show an absence of alveolar structures (Oakes et al. 2008). Prolactin and progesterone act at least in part by inducing receptor activator for nuclear factor $\kappa$ B ligand (RANKL) expression, and Rankl null mice fail to undergo lobuloalveolar differentiation and therefore do not lactate (Fata et al. 2000b). Other regulatory components downstream of prolactin signaling include amphiregulin and GATA3. As the ovarian hormones subside with aging and the reproductive cycles cease, the mammary tissue undergoes irreversible lobuloalveolar regression acquiring a dormant state. A notable feature of the hormone-directed mammary remodeling program is the dependence on stromal-epithelial crosstalk arising from the distribution of specific ligands and their receptors across these compartments.

\section{Epithelial Morphogens and Inhibitors}

Embryonic mammary development precedes endocrine hormones and involves a number of local factors: Wnt for milk line specification and placode size; FGFs for initiation of mammary cell fate; and EGFR ligands for the number and positioning of mammary glands. On the other hand, repression of Hedgehog signaling specifies a follicular versus glandular epithelial cell fate decision (Robinson 2007; Watson and Khaled 2008). Instructive paracrine signaling is seen as early as the development of mammary-specific mesenchyme, whereby parathyroid hormone-related protein $(\mathrm{PTHrP})$ in the embryonic mammary bud epithelium interacts with its receptor PTHR1 on the adjacent mesenchymal cells. At puberty, a number of signaling pathways serve specific functions in TEB proliferation, ductal elongation and side branching. As discussed earlier, IGFR1 downstream of stromal IGF1 provides the first response to endocrine hormones at this stage. The canonical Wnt signaling pathway is also required early on as defects in embryonic mammary glands or mammary bud formation arise in mice genetically modulated in Wnt ligands, their 
transcriptional targets, or the Wnt inhibitor Dickkopf-1 (Hens and Wysolmerski 2005; Turashvili et al. 2006). Wnt-4 is induced by progesterone in the mammary epithelial cells and plays an essential role in side branching during pregnancy (Brisken et al. 2000). Among the FGF family members, Fgf10 and Fgf7 expression is noted during the embryonic placode formation, and Fgfr2 is found to function in TEBs (Lu et al. 2008; Sternlicht et al. 2006). A deficiency of many of the above molecules results in defective early mammary development; however, their adult remodeling-related phenotypes remain unresolved. The EGFR signaling is required for adequate branching morphogenesis, and of its seven ligands, amphiregulin has emerged to be the most critical. Via a paracrine mode of action, epithelial-derived amphiregulin activates the EGFR located on the stromal cells (Sternlicht et al. 2005). Exogenous estradiol induces tyrosine phosphorylation of EGFR as well as ErbB2 in ovariectomized mice, which is also observed in pubertal mammary glands (Sebastian et al. 1998). Intriguingly, ErbB2, which heterodimerizes with EGFR or other ErbB receptors, is required in the epithelium for normal ductal development (Jackson-Fisher et al. 2004; Andrechek et al. 2005), whereas ErbB4 is required for lobuloalveologenesis during pregnancy (Tidcombe et al. 2003). Factors that play important local functions in maintaining the TEB or ductal morphology include netrin-1 and its receptor neogenin (Srinivasan et al. 2003) and a cell surface morphogen epimorphin (Radisky et al. 2003). GATA3 is a transcription factor enriched in the pubertal mammary glands and especially found in the body cells of invading TEBs. GATA3 is critical for mammary morphogenesis and maintenance of luminal differentiation in the adult mammary gland (Kouros-Mehr et al. 2006; AsselinLabat et al. 2007; Chou et al. 2010).

In opposition to the above mitogens, TGF $\beta$ negatively regulates mammary gland development (Barcellos-Hoff and Ewan 2000) as has been shown by the use of mice deficient in these mitogens, their receptors or downstream signaling effector molecules (Cheng et al. 2005; Serra and Crowley 2005). Effects of TGF $\beta$ on normal mammary remodeling are mediated through signaling in both the epithelial and stromal compartments. Epithelial-derived TGF $\beta$ activates signaling in the stromal compartment, and also exerts autocrine effects. TGF $\beta$ inhibits epithelial proliferation, facilitates the formation of an open ductal pattern during branching morphogenesis because of its local inhibitory effects, and stimulates ECM production (Hinck and Silberstein 2005). It inhibits forward movement of the duct. The secreted protein also acts on periductal targets. Mice that express TGF $\beta$ during gestation via the whey acidic protein promoter have normal branching morphogenesis, but defective development of secretory epithelium because of apoptosis of differentiating alveolar cells. This phenotype is also displayed by mice expressing activated TGF $\beta$ RI in the mammary epithelium. Conversely, dominantnegative interference with TGF $\beta$ signaling leads to precocious alveolar development (Serra and Crowley 2005). The dual role of TGF $\beta$ in inhibiting the expression of ECM-degrading proteases, whereas inducing the production of protease inhibitors, sulfated gycosaminoglycans and many ECM proteins is well known. It also counters the expression of hepatocyte growth factor (HGF) but induces PTHrP (Kamalati et al. 1999; Dunbar et al. 2001). Other inhibitors of mammary gland remodeling include the Sproutys, which may act by antagonizing FGFR, EGFR, or IGFRI signaling (Sternlicht et al. 2006). Interestingly, many of the morphogens and inhibitors play similar functions in other tissues with branched structures such as the kidney, salivary gland, lung epithelium, blood vessels, and nerves (Liu et al. 2008).

\section{Stromal Extracellular Matrix Modifiers}

Mammary stroma remodels concurrently with the epithelial ductal tree. It plays an essential role in organ homeostasis and is capable of redirecting the fate of transplanted testicular cells into generating a functional epithelial branching network (Boulanger et al. 2007). A large part of the stroma is the structural ECM, which is also believed to be an important component of the mammary stem cell niche 
(Wiseman and Werb 2002; Chepko and Dickson 2003; Brisken and Duss 2007). The collective activity of metalloproteinases is sufficient to degrade all proteins of the ECM network, and relevant within the metalloproteinase superfamily are the classes of matrix metalloproteinases (MMPs), ADAMs, and their biological inhibitors TIMPs (Cruz-Munoz and Khokha 2008; Murphy 2008; Murphy and Nagase 2008; Kessenbrock et al. 2010). These genes show specific spatiotemporal expression patterns in female reproductive tissues at discrete mammary stages. Their mRNA and protease activity are evident during branching morphogenesis and involution (Talhouk et al. 1991; Witty et al. 1995; Fata et al. 1999, 2000a; Green and Lund 2005); many are produced by periductal fibroblasts (MMP2, MMP3), others (MMP14, TIMPs 1, 3, 4) are expressed by both epithelial and stromal cells, whereas some members are only present in epithelial cells (MMP7, TIMP2) or predominant in the local immune cells (MMP9). MMP14 is concentrated in the TEBs and has been found in myoepithelial cells, which also express TIMP3 (Wiseman et al. 2003; Fata et al. 2004). Interestingly, MMP14 expressing cells localize to the leading edge of engineered mammary ducts (Mori et al. 2009).

TEB bifurcation involves stromal matrix deposition for bifurcation whereas side branching requires extension through the layer of myoepithelial cells, degradation of the basement membrane that surrounds mature epithelial ducts followed by invasion of the periductal layer of fibrous stromal tissue. Therefore, these two processes may differentially use metalloproteinase activity (Wiseman and Werb 2002). Of the 24 MMPs, nine active ADAMs, and four TIMPs, only a few have been studied in various aspects of the remodeling mammary gland, and their specific contributions to the processes of TEB growth and bifurcation, ductal elongation, secondary or tertiary branching, as well as the rate of mammary involution have been revealed through mice lacking these genes (Page-McCaw et al. 2007). Noteworthy is the finding that epithelial ADAM17 is required for mammary development and is the critical sheddase for the release of amphiregulin (Sternlicht et al. 2005). MMP2 null mice have deficient mammary ductal invasion but excessive secondary branching, whereas mice lacking MMP3 show defective side branching. On the other hand, mice overexpressing MMP3 or MMP14 have excessive side branching, precocious alveologenesis, and eventually develop mammary tumors (Witty et al. 1995; Sternlicht et al. 1999; $\mathrm{Ha}$ et al. 2001). Antisense down-regulation of epithelial TIMP1 results in enhanced ductal elongation and supernumerary branching (Fata et al. 1999). When slow-release pellets were used to compare the local effects of individual TIMPs on pubertal mammary morphogenesis, TIMP1, TIMP3, and TIMP4 inhibited ductal elongation, whereas TIMP2 promoted this process (Hojilla et al. 2007). This may in part arise from increased MMP2 activity in TIMP2 enriched glands, related to the adaptor function of TIMP2 in the MMP14/TIMP2/MMP2 trimolecular complex, which is essential for the cell surface activation of MMP2 (Ellerbroek and Stack 1999; English et al. 2006). Currently, the effects of ovarian hormones on the expression of individual metalloproteinases or their inhibitors are not very well characterized, although a few are altered (MMP9, MMP13; TIMP3, and TIMP4) at the diestrus phase of the murine reproductive cycle. Indeed, progesterone-induced signaling through the PR-A isoform induces MMP2 activity and this coincides with the loss of laminin-5, collagens type III and IV, and basement membrane integrity, and the development of hyperplasia in PR-A transgenic mice (Simian et al. 2009).

The extracellular proteases are generally more abundant during mammary involution as this involves copious restructuring of the mammary gland, whereas their expression is inhibited during lactation (Sorrell et al. 2005). Microarray expression profiling has shown that MMP3, MMP14, and ADAM9 are markedly up-regulated during pregnancy and involution, and MMP3, MMP7, and MMP12 are induced at involution, with MMP3 showing the most profound elevation. Implantation of TIMP1 pellets during postlactational involution retards this process (Talhouk et al. 1992), whereas TIMP3 deficiency accelerates this mammary involution 
(Fata et al. 2001b). In addition to MMPs, there is evidence to support a role for the serine protease plasminogen in mammary tissue remodeling, as plasminogen null mice show compromised lactation and involution (Lund et al. 2000). On the whole, fluctuations in the plasminogen system are not as pronounced as those in the metalloproteinases, although urokinase plasminogen activator is induced along with its endogenous inhibitor during involution (Sorrell et al. 2005).

The above studies underscore the importance of the stromal ECM in the remodeling mammary gland; however, there is a major gap in our ability to comprehend changes that occur in the three-dimensional ECM network. This arises from technical limitations in studying the ECM at high resolution in its entirety in an intact organ. Second harmonic generation imaging using a multiphoton laser has opened new possibilities along these lines (Brown et al. 2003; Ingman et al. 2006), allowing the visualization of the type I collagen fiber network within the mammary gland, as shown in Figure 2 (McKee and R. Khokha, unpubl.). This technology may especially allow detailed interrogation of the effect of aberrations in matrix remodeling or mechanotransduction on mammary reprogramming.

\section{Immune Cells}

A role for immune cells has been postulated in mammary gland remodeling, based on microarray expression profiling of involuting murine mammary glands (Clarkson et al. 2004; Stein et al. 2004). Briefly, two distinct immune phases are likely: an early phase with transient expression of death receptors and proinflammatory cytokines, and a delayed phase with increased monocyte and lymphoid cytokine/chemokine expression associated with cell death and tissue remodeling. Several death-receptor ligands such as tumor necrosis factor $\alpha(\mathrm{TNF} \alpha)$, TWEAK (CD255), and Fas ligand are rapidly stimulated and thought to provide apoptotic signals during mammary involution. With respect to the involvement of immune cells per se, macrophages are found localized along the neck of
TEBs, developing alveolar structures at gestation, and in the involuting mammary gland. The depletion of leukocytes by $\gamma$-irradiation or in CSF1 null mice has revealed their requirement for proper TEB outgrowth (Gouon-Evans et al. $2000,2002)$. Here, macrophages are thought to contribute to ductal invasion through the release of factors that promote growth, angiogenesis, and ECM breakdown. Macrophages may serve a similar role in pregnancy, as CSF1 deficient mice show an imbalanced ductal structure with reduced branching but increased lobuloalveologenesis (Pollard and Hennighausen 1994). Involution has been identified to be another stage associated with an early influx of neutrophils closely followed by macrophages and lymphocytes (Atabai et al. 2007). Eosinophils, mast cells, and dendritic cells are also recruited during mammary development, although their function is less well understood. Immune cells constitute an important part of the mammary stroma, and much remains to be understood about the functional contribution of individual immune cell populations, as well as the mechanisms that regulate their influx and/or activity. We have found that the rapid postlactational mammary involution in TIMP3 null mice is associated with increased macrophage and lymphocytic infiltration into the mammary gland (C.V. Hojilla and R. Khokha, unpubl.). Interestingly, plasma kallikrein, a serine protease localized to mast cells, is found in the mammary stroma at puberty and during postlactational involution. Inhibition of plasma kallikrein delays alveolar apoptosis, adipocyte replenishment, and stromal remodeling in the involuting mammary gland (Lilla et al. 2009).

\section{Mammary Stem Cells}

Mammary stem cells have generally been thought to be quiescent, located in specialized niche(s), and lacking estrogen and progesterone receptors (Asselin-Labat et al. 2006; Brisken and Duss 2007). Recently, specific cell surface markers (mouse: heat stable antigen, CD24; $\alpha 6$ integrin, CD49f; $\beta 1$ integrin, CD29; $\beta 3$ integrin, CD61; and human: $\alpha 6$ integrin, CD49f; EPCAM/ESA) have been identified, which 
resolve murine or human mammary epithelial cells into distinct cell populations (Stingl et al. 2005, 2006a,b). Murine mammary epithelial cells with specific signatures $\left(\mathrm{CD} 24^{+} \mathrm{CD} 29^{\mathrm{hi}}\right.$ CD49f ${ }^{\text {hi }}$ ) can repopulate the mammary gland and are thus enriched in mammary stem cells, whereas others $\left(\mathrm{CD} 24^{+} \mathrm{CD} 29^{\mathrm{lo}} / \mathrm{CD} 49 \mathrm{f}^{\mathrm{lo}}\right)$ possess progenitor activity (Shackleton et al. 2006). This characterization is providing opportunities to elucidate mammary stem cell status during the periods of mammary tissue remodeling. We and others have shown that murine mammary stem cells show dynamic fluctuations, increasing as much as 14 -fold during the progesterone-driven luteal phase of the reproductive cycle (Joshi et al. 2010), and 11-fold during gestation (Asselin-Labat et al. 2010). Progesterone also induces the mammary stem cell expansion, likely through a paracrine effect, by inducing the expression of RANKL and Wnt4 in luminal cells while up-regulating their cognate receptors in myoepithelial cells (Joshi et al. 2010). Because much of mammary remodeling is triggered in response to the ovarian hormones, these studies provide important evidence for the effects of steroid hormones on the expansion of the mammary stem cell pool at specific remodeling stages of the adult gland. As discussed earlier, female reproductive history and sustained exposure to estrogen and progesterone are well established risk factors for breast cancer. Understanding the link between reproductive hormones, mammary stem cells, and mammary gland remodeling will bring new insights into the molecular basis for this increased risk.

\section{METALLOPROTEINASES INTEGRATE MAMMARY REPROGRAMMING}

Mammary gland remodeling requires an integration of the above platforms and the metalloproteinases have the capacity to orchestrate these networks at the stromal-epithelial interface. They do so by a number of means including: (1) facilitating paracrine mode of action across stroma-epithelium, (2) regulating master signals and lateral engagement of multiple signals, and (3) synchronizing parenchymal, matrix and immune cell homeostasis.

\section{Paracrine Signaling}

A recurrent theme during mammary remodeling is paracrine signaling, which necessitates the delivery of a growth factor, or cytokine from the stromal to epithelial compartment, luminal epithelial cells to myoepithelial cells, or vice versa. Given their property of ectodomain-shedding, the membrane-anchored metalloproteinases have a prominent regulatory function in providing biochemical cues. A fine example of this is the ADAM17-mediated shedding of epithelial cell surface amphiregulin for its binding to stromal EGFR during mammary morphogenesis (Sternlicht et al. 2005). In fact ADAM17 and ADAM10 have emerged as the key transmembrane enzymes for shedding of the seven EGFR ligands: ADAM17 as the principal sheddase for TGF $\alpha$, HB-EGF, amphiregulin, epiregulin, and epigen; and ADAM10 as the major sheddase for EGF and betacellulin (Blobel et al. 2009). In fact, many of the critical ligands discussed in previous sections are also subject to processing by transmembrane or soluble metalloproteinases, although the functional link between specific proteases and ligands have not yet been shown to operate in the mammary gland. A number of MMPs (MMP1, 2, 3, 9, and 11) can potentially release IGFs from their binding proteins present in the circulation or the interstitium (Hojilla et al. 2003), before the interaction of IGFs with their tyrosine kinase receptor IGFIR. In the liver, TIMP1 overexpression inhibits the release of IGF2 complexed to the IGF binding proteins and interferes with IGFIR signaling blocking hepatocyte transformation (Martin et al. 1999). Further, ECMbound ligands such as TGF $\beta$ and HGF exist in latent form and require proteolytic processing for their maturation and subsequent signal transduction (Mohammed and Khokha 2005; Jenkins 2008). HGF signaling via c-Met receptor is altered on genetic modulation of TIMP1 expression in the remodeling liver (Mohammed et al. 2005), whereas TGF $\beta 1$ activity as measured by Smad phosphorylation is aberrant 
in the remodeling TIMP3 null hearts (Kassiri et al. 2009).

\section{Master Signals}

Although multiple mitogens or inhibitors direct mammary remodeling processes, some apparently play more prominent functions. TGF $\beta$, EGFR activation via amphiregulin, and Wnts can be categorized as such. Activities of both the serine protease plasmin and MMP2 are implicated in the conversion of ECM-bound proTGF $\beta$ into its active form (Jenkins 2008). TGF $\beta$ exerts a wide-ranging control over mammary epithelial cell proliferation and morphology. It regulates ECM remodeling, as it allows ECM deposition while inhibiting ECM degrading proteases in the immediate vicinity of the end buds and branching ducts. In turn this facilitates the generation of an ECM obstacle or collar for tubular morphology. Additionally, TGF $\beta$ transcriptionally regulates several MMPs and TIMP genes during tissue remodeling (Wilkins-Port and Higgins 2007; Kassiri et al. 2009). Thus, although MMPs enhance TGF $\beta$ bioavailability, TGF $\beta$ in turn controls the expression of proteases. A similar dual regulation may also apply for EGFR activation, which is itself linked to ADAM17 activity in the mammary gland and, in turn, can induce metalloproteinase expression (Blobel 2005; Sternlicht et al. 2005; Wilkins-Port and Higgins 2007). Such a mechanism of positive feedback uniquely empowers these enzymes as useful integrators during remodeling programs. Moreover, ADAM17 is implicated in the ectodomain cleavage of ErbB4, an activity typically followed by subsequent cleavage by the $\gamma$-secretase complex to trigger nuclear localization and signaling from this receptor. With respect to Wnt activity, TIMP3 deficiency leads to increased $\beta$-catenin signaling in primary mammary epithelial cells and expression of epithelial-specific MMP7, which is a key transcriptional target of Lef/Tcfs downstream of canonical Wnt signaling (Hojilla et al. 2007). Although Wnt signaling is important for multiple aspects of the mammary gland including the mammary stem cells (Brisken and Duss 2007), little is currently known of the mechanisms by which secreted Wnt ligands are sequestered extracellularly and made available to their receptors. Interestingly, deficiency of syndecan-1, a cell surface heparan sulfate proteoglycan reduced mammary development (Dontu et al. 2003) and profoundly affects Wnt-induced mammary tumorigenesis in mice (Alexander et al. 2000). Moreover, ectodomain shedding of syndecan- 1 and syndecan- 4 occurs by a TIMP3 regulatable metalloproteinase (Alexander et al. 2000; Fitzgerald et al. 2000).

Compared to the remodeling of the epithelial ductal network, restructuring of the vascular network during mammary remodeling is less well understood. Mice lacking VEGF because of keratin 5 promoter driven Cre show that VEGF is partially dispensable for angiogenesis during pregnancy, but its loss impacts lobuloalveolar development and mammary differentiation at lactation (Rossiter et al. 2007). VEGF is a critical factor in vascular biology and indeed its bioavailability is mediated by MMP activity (Bergers et al. 2000).

The act of tissue remodeling is the cumulative outcome of balanced survival/death signals or pro-/anti-inflammatory cues, and the repertoire of substrates subject to metalloproteinase-mediated processing continues to expand (Murphy et al. 2008). ADAM17 and its physiological inhibitor TIMP3 constitute an important metalloproteinase axis, which can concurrently influence a number of signal transduction pathways. For instance, EGFR survival signaling and TNFR cell death signaling are linked to metalloproteinase-mediated release of EGF ligands (TGF $\alpha$, HB-EGF, and amphiregulin) or of TNF and its two receptors (TNFR1 and TNFR2). Indeed parallel effects on these two central pathways have been observed in liver challenged with death receptor activation. Here, the transmembrane metalloproteinase ADAM17 and its stromal inhibitor TIMP3 provide a powerful regulatory mechanism for regulating MAPK-dependent stress signaling downstream of EGFR and TNFR1 as well as the survival outcome of the organism (Murthy et al. 2010). Similarly, in the 
remodeling heart, TIMP3 simultaneously impacts TGF $\beta$ and TNF signaling pathways, which respectively exert anti-inflammatory and proinflammatory effects (Kassiri et al. 2009). Although both types of stimuli are required in remodeling organs, including the mammary gland, their temporal integration is essential for constructive tissue remodeling. Overall, the typical positioning of metalloproteinases and their inhibitors at the stromal-epithelial interface, where ligand-receptor interactions occur, provides a means for engaging multiple and diverse signal transduction pathways (Fig. 3). It must be recognized however, that the same ligand or signal can produce vastly different biological outcomes because of context-dependent

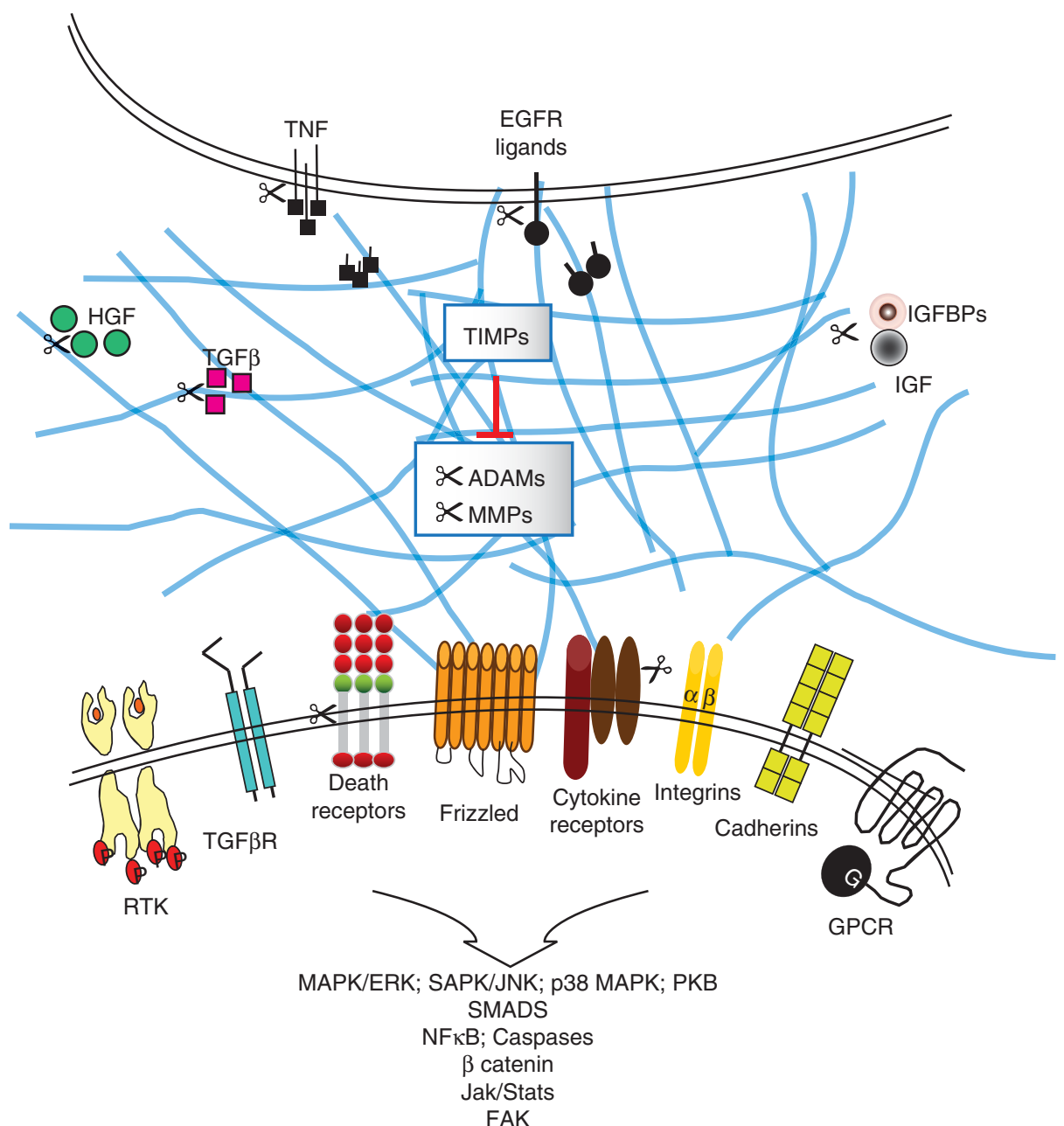

Figure 3. Lateral integration of critical signal transduction pathways by metalloproteinase activity. TIMPs together with MMP and ADAM proteases operate at the stromal-epithelial interface to affect growth factor bioavailability by regulating the release of ECM bound factors, shedding of cell surface ligands and cytokines or their receptors, as well as alter the release of factors complexed with their binding proteins. ADAM, a disintegrin and a metalloproteinase; EGFR, epidermal growth factor receptor; GPCR, G-protein coupled receptor; HGF, hepatocyte growth factor; IGF, insulin-like growth factor; IGFBPs, IGF binding proteins; MMP, matrix metalloproteinase; RTK, receptor tyrosine kinase; TGF $\beta$, transforming growth factor beta; TIMP, tissue inhibitor of metalloproteinase; TNF, tumor necrosis factor. 
effects (reviewed in Egeblad and Werb [2002]; Kessenbrock et al. [2010]).

Synchronizing Parenchymal, Stromal, and Extracellular Matrix Homeostasis

The earlier examples illustrate a role for proteases in the lateral integration of specific signal transduction pathways, which dictate the cellular turnover. This, however, must occur synchronously with remodeling of the structural matrix within the mammary gland, along with the infiltration of relevant immune cells into the remodeling tissue. MMPs were initially discovered as the ECM cleaving enzymes, and a vast early literature has documented their expression and function during numerous developmental aspects including the remodeling of reproductive tissues. Beyond governing ECM integrity, which confines cells to specific compartments, proteolytic modulation alters the availability of ligands that interact with the cell surface integrin receptors mediating cell adhesion and cell motility (Xu et al. 2009). Protease activity also affects growth stimulatory signals via the release of cryptic bioactive ECM fragments, such as from laminin 5 , which can provide new signals for cellular alterations (Schenket al. 2003). The ability of these enzymes to release TGF $\beta$, EGF, and TNF, and, in turn, be transcriptionally regulated by the same growth factors not only creates a positive feedback loop but also reveals a mechanism for closely orchestrating ECM deposition and/or degradation with that of cell proliferation and cell death.

Another mode by which metalloproteinases facilitate deconstruction of the mammary gland during remodeling is by ectodomain cleavage of cell adhesion proteins such as Ecadherin, which must be intact to provide a strong survival signal for mammary epithelial cells. MMPs have been implicated in the processing of E-cadherin (Noe et al. 2001). Indeed, excessive E-cadherin cleavage occurs during the accelerated loss of the epithelial compartment and gain of adipocyte reconstitution at postlactational mammary involution in TIMP3 deficient mice (Fata et al. 2001b). In contrast, TIMP1 slow-release pellets retard mammary remodeling at this physiological window (Lee et al. 1984; Talhouk et al. 1992). In the past decade, metalloproteinase substrates have also been found situated at the apex of cytokine cascades, immune cell influx, and immune cell development (Murphy et al. 2008; Kessenbrock et al. 2010). Although there is considerable evidence for altered immunity and/or inflammation as a function of specific deficiencies of metalloproteinases and TIMPs (Mohammed et al. 2004; Smookler et al. 2006; Weskamp et al. 2006; Horiuchi et al. 2007), the function of these genes on immune cell homeostasis in the mammary gland remains largely unexplored. Overall, the endocrine hormone-triggered delivery of biochemical signals is aligned with the physical alterations taking place in the matrix and changes in immune cell milieu.

\section{METALLOPROTEINASES AS FACILITATORS OF THE TUMOR MICROENVIRONMENT}

A tightly controlled remodeling program is responsible for preserving the fundamental form and function of the mammary gland, whereas deregulated metalloproteinase activity subverts normal remodeling programs to facilitate neoplasia (Wiseman and Werb 2002; Lanigan et al. 2007). At the earliest stages of cellular transformation, tissue loses its organized architecture including cellularity and polarity, which is further exacerbated by the loss of cell-cell and cell-ECM adhesion. Stroma is important in normal mammary remodeling and also an active contributor of tumor progression. Given the normal role of metalloproteinases in processing critical morphogens and inhibitors involved in remodeling, deregulation of these enzymes directly impacts the abundance of survival and death signals within the microenvironment of the transformed cell. Because many of these factors are key transcriptional inducers of the metalloproteinase and/or inhibitor families, this creates reciprocal signaling circuits towards promotion of the transformed state. Such positive feedback loops also exist between specific metalloproteinases and cytokines, which influence inflammatory 
cell influx into the tumor as well as the nature of the inflammatory reaction. Increased MMP expression has been classically shown to enhance tumor invasion and angiogenesis through both ECM degradation and the release of sequestered morphogens. Ovarian hormones have been linked to increased breast cancer risk, and their effects on mammary stem cells are now emerging; however, the regulation of metalloproteinases and their inhibitors by these hormones as well as the precise spatiotemporal regulation of many critical events in the tissue microenvironment is not well known. In the remodeling mammary gland, a regenerative pool of stem cells resides in a specialized niche and stem cells are increasingly recognized as targets of malignant transformation in cancer. The dynamics of proteolytic events that affect the stem cell niche and thus predispose stem cells to cancer have not been explored.

\section{SUMMARY}

Mammary development and remodeling requires overarching programs to bring ordered cell-cell interactions within and across epithelial and stromal compartments in response to system-wide cues as well as those generated in the immediate cell microenvironment. A series of events begin to unfold with the induction of systemic mammogens, which initiate specific responses in the stroma or epithelium and involve regulated stromal-epithelial cross-talk, which dictate epithelial morphogenesis throughout the remodeling cycles in female lifespan. Metalloproteinases are the major extracellular proteases operating at the stromal-epithelial interface and their regulated activity is key to a well-orchestrated remodeling program.

\section{ACKNOWLEDGMENTS}

This work was supported by grants from the Canadian Cancer Society Research Institute and Canadian Institutes of Health Research to R.K., and CA057621 and ES019458 from the National Cancer Institute and National Institute of Environmental Sciences to Z.W.

\section{REFERENCES}

Affolter M, Bellusci S, Itoh N, Shilo B, Thiery JP, Werb Z. 2003. Tube or not tube: Remodeling epithelial tissues by branching morphogenesis. Dev Cell 4: 11-18.

Akbari A, Razzaghi Z, Homaee F, Khayamzadeh M, Movahedi M, Akbari ME. 2010. Parity and breastfeeding are preventive measures against breast cancer in Iranian women. Breast Cancer doi: 10.1007/s12282-010-0203-z.

Alexander CM, Reichsman F, Hinkes MT, Lincecum J, Becker KA, Cumberledge S, Bernfield M. 2000. Syndecan-1 is required for Wnt-1-induced mammary tumorigenesis in mice. Nat Genet 25: 329-332.

Alexander CM, Selvarajan S, Mudgett J, Werb Z. 2001. Stromelysin-1 regulates adipogenesis during mammary gland involution. J Cell Biol 152: 693-703.

Anderson CH, Beattie CW. 1992. Cellular kinetics of rat mammary gland terminal end bud epithelium exposed to $N$-methyl-N-nitrosourea in vivo. Cancer Res 52: 5076-5081.

Andrechek ER, White D, Muller WJ. 2005. Targeted disruption of ErbB2/Neu in the mammary epithelium results in impaired ductal outgrowth. Oncogene 24: 932-937.

Asselin-Labat ML, Shackleton M, Stingl J, Vaillant F, Forrest NC, Eaves CJ, Visvader JE, Lindeman GJ. 2006. Steroid hormone receptor status of mouse mammary stem cells. J Natl Cancer Inst 98: 1011-1014.

Asselin-Labat ML, Sutherland KD, Barker H, Thomas R, Shackleton M, Forrest NC, Hartley L, Robb L, Grosveld FG, van der Wees J, et al. 2007. Gata-3 is an essential regulator of mammary-gland morphogenesis and luminalcell differentiation. Nat Cell Biol 9: 201-209.

Asselin-Labat ML, Vaillant F, Sheridan JM, Pal B, Wu D, Simpson ER, Yasuda H, Smyth GK, Martin TJ, Lindeman GJ, et al. 2010. Control of mammary stem cell function by steroid hormone signalling. Nature 465: 798-802.

Atabai K, Sheppard D, Werb Z. 2007. Roles of the innate immune system in mammary gland remodeling during involution. J Mammary Gland Biol Neoplasia 12: 37-45.

Barcellos-Hoff MH, Ewan KB. 2000. Transforming growth factor- $\beta$ and breast cancer: Mammary gland development. Breast Cancer Res 2: 92-99.

Bergers G, Brekken R, McMahon G, Vu TH, Itoh T, Tamaki K, Tanzawa K, Thorpe P, Itohara S, Werb Z, et al. 2000. Matrix metalloproteinase- 9 triggers the angiogenic switch during carcinogenesis. Nat Cell Biol 2: 737-744.

Blobel CP. 2005. ADAMs: Key components in EGFR signalling and development. Nat Rev Mol Cell Biol 6: 32-43.

Blobel CP, Carpenter G, Freeman M. 2009. The role of protease activity in ErbB biology. Exp Cell Res 315: 671-682.

Bonnette SG, Hadsell DL. 2001. Targeted disruption of the IGF-I receptor gene decreases cellular proliferation in mammary terminal end buds. Endocrinology 142: 4937-4945.

Boudreau N, Bissell MJ. 1998. Extracellular matrix signaling: Integration of form and function in normal and malignant cells. Curr Opin Cell Biol 10: 640-646.

Boulanger CA, Mack DL, Booth BW, Smith GH. 2007. Interaction with the mammary microenvironment redirects spermatogenic cell fate in vivo. Proc Natl Acad Sci 104: 3871-3876. 
Boyd NF, Martin LJ, Yaffe M, Minkin S. 2009. Mammographic density. Breast Cancer Res 11: S4.

Brisken C, Duss S. 2007. Stem cells and the stem cell niche in the breast: An integrated hormonal and developmental perspective. Stem Cell Rev 3: 147-156.

Brisken C, Heineman A, Chavarria T, Elenbaas B, Tan J, Dey SK, McMahon JA, McMahon AP, Weinberg RA. 2000. Essential function of Wnt-4 in mammary gland development downstream of progesterone signaling. Genes Dev 14: $650-654$.

Brisken C, Kaur S, Chavarria TE, Binart N, Sutherland RL, Weinberg RA, Kelly PA, Ormandy CJ. 1999. Prolactin controls mammary gland development via direct and indirect mechanisms. Dev Biol 210: 96-106.

Brisken C, Park S, Vass T, Lydon JP, O'Malley BW, Weinberg RA. 1998. A paracrine role for the epithelial progesterone receptor in mammary gland development. Proc Natl Acad Sci 95: 5076-5081.

Brown E, McKee T, diTomaso E, Pluen A, Seed B, Boucher Y Jain RK. 2003. Dynamic imaging of collagen and its modulation in tumors in vivo using second-harmonic generation. Nat Med 9: 796-800.

Butcher DT, Alliston T, Weaver VM. 2009. A tense situation: Forcing tumour progression. Nat Rev Cancer 9: 108-122.

Cardiff RD, Wellings SR. 1999. The comparative pathology of human and mouse mammary glands. J Mammary Gland Biol Neoplasia 4: 105-122.

Cheng N, Bhowmick NA, Chytil A, Gorksa AE, Brown KA, Muraoka R, Arteaga CL, Neilson EG, Hayward SW, Moses HL. 2005. Loss of TGF-beta type II receptor in fibroblasts promotes mammary carcinoma growth and invasion through upregulation of TGF- $\alpha-$, MSPand HGF-mediated signaling networks. Oncogene 24: 5053-5068.

Chepko G, Dickson RB. 2003. Ultrastructure of the putative stem cell niche in rat mammary epithelium. Tissue Cell 35: 83-93.

Chou J, Provot S, Werb Z. 2010. GATA3 in development and cancer differentiation: Cells GATA have it! J Cell Physio 222: $42-49$.

Clarkson RW, Wayland MT, Lee J, Freeman T, Watson CJ. 2004. Gene expression profiling of mammary gland development reveals putative roles for death receptors and immune mediators in post-lactational regression. Breast Cancer Res 6: R92-R109.

Cruz-Munoz W, Khokha R. 2008. The role of tissue inhibitors of metalloproteinases in tumorigenesis and metastasis. Crit Rev Clin Lab Sci 45: 291-338.

Dontu G, Abdallah WM, Foley JM, Jackson KW, Clarke MF Kawamura MJ, Wicha MS. 2003. In vitro propagation and transcriptional profiling of human mammary stem/progenitor cells. Genes Dev 17: 1253-1270.

Dunbar ME, Dann P, Brown CW, Van Houton J, Dreyer B, Philbrick WP, Wysolmerski JJ. 2001. Temporally regulated overexpression of parathyroid hormone-related protein in the mammary gland reveals distinct fetal and pubertal phenotypes. J Endocrinol 171: 403-416.

Egeblad M, Werb Z. 2002. New functions for the matrix metalloproteinases in cancer progression. Nat Rev Cancer 2: $161-174$.
Ellerbroek SM, Stack MS. 1999. Membrane associated matrix metalloproteinases in metastasis. Bioessays 21: 940-949.

English JL, Kassiri Z, Koskivirta I, Atkinson SJ, Di Grappa M, Soloway PD, Nagase H, Vuorio E, Murphy G, Khokha R. 2006. Individual Timp deficiencies differentially impact pro-MMP-2 activation. J Biol Chem 281: 10337-10346.

Fata JE, Chaudhary V, Khokha R. 2001a. Cellular turnover in the mammary gland is correlated with systemic levels of progesterone and not 17beta-estradiol during the estrous cycle. Biol Reprod 65: 680-688.

Fata JE, Werb Z, Bissell MJ. 2004. Regulation of mammary gland branching morphogenesis by the extracellular matrix and its remodeling enzymes. Breast Cancer Res 6: $1-11$.

Fata JE, Ho AT, Leco KJ, Moorehead RA, Khokha R. 2000a Cellular turnover and extracellular matrix remodeling in female reproductive tissues: Functions of metalloproteinases and their inhibitors. Cell Mol Life Sci 57: 77-95.

Fata JE, Kong YY, Li J, Sasaki T, Irie-Sasaki J, Moorehead RA, Elliott R, Scully S, Voura EB, Lacey DL, et al. 2000b. The osteoclast differentiation factor osteoprotegerin-ligand is essential for mammary gland development. Cell 103: $41-50$.

Fata JE, Leco KJ, Moorehead RA, Martin DC, Khokha R. 1999. Timp-1 is important for epithelial proliferation and branching morphogenesis during mouse mammary development. Dev Biol 211: 238-254.

Fata JE, Leco KJ, Voura EB, Yu HY, Waterhouse P, Murphy G, Moorehead RA, Khokha R. 2001b. Accelerated apoptosis in the Timp-3-deficient mammary gland. J Clin Invest 108: $831-841$.

Fitzgerald ML, Wang Z, Park PW, Murphy G, Bernfield M. 2000. Shedding of syndecan- 1 and -4 ectodomains is regulated by multiple signaling pathways and mediated by a TIMP-3-sensitive metalloproteinase. J Cell Biol 148: $811-824$.

Gouon-Evans V, Lin EY, Pollard JW. 2002. Requirement of macrophages and eosinophils and their cytokines/ chemokines for mammary gland development. Breast Cancer Res 4: 155-164.

Gouon-Evans V, Rothenberg ME, Pollard JW. 2000. Postnatal mammary gland development requires macrophages and eosinophils. Development 127: 2269-2282.

Green KA, Lund LR. 2005. ECM degrading proteases and tissue remodelling in the mammary gland. Bioessays 27 894-903.

Ha HY, Moon HB, Nam MS, Lee JW, Ryoo ZY, Lee TH, Lee KK, So BJ, Sato H, Seiki M, et al. 2001. Overexpression of membrane-type matrix metalloproteinase-1 gene induces mammary gland abnormalities and adenocarcinoma in transgenic mice. Cancer Res 61: 984-990.

Hens JR, Wysolmerski JJ. 2005. Key stages of mammary gland development: Molecular mechanisms involved in the formation of the embryonic mammary gland. Breast Cancer Res 7: 220-224.

Hinck L, Silberstein GB. 2005. Key stages in mammary gland development: The mammary end bud as a motile organ. Breast Cancer Res 7: 245-251. 
Hojilla CV, Mohammed FF, Khokha R. 2003. Matrix metalloproteinases and their tissue inhibitors direct cell fate during cancer development. Br J Cancer 89: 1817-1821.

Hojilla CV, Kim I, Kassiri Z, Fata JE, Fang H, Khokha R. 2007. Metalloproteinase axes increase $\beta$-catenin signaling in primary mouse mammary epithelial cells lacking TIMP3. J Cell Sci 120: 1050-1060.

Horiuchi K., Kimura T. , Miyamoto T, Takaishi H, Okada Y, Toyama Y, Blobel CP. 2007. Cutting edge: TNF- $\alpha-$ converting enzyme (TACE/ADAM17) inactivation in mouse myeloid cells prevents lethality from endotoxin shock. J Immunol 179: 2686-2689.

Humphreys RC, Lydon J, O’Malley BW, Rosen JM. 1997. Mammary gland development is mediated by both stromal and epithelial progesterone receptors. Mol Endocrinol 11: 1-11.

Ingman WV, Wyckoff J, Gouon-Evans V, Condeelis J, Pollard JW. 2006. Macrophages promote collagen fibrillogenesis around terminal end buds of the developing mammary gland. Dev Dyn 235: 3222-3229.

Jackson-Fisher AJ, Bellinger G, Ramabhadran R, Morris JK, Lee KF, Stern DF. 2004. ErbB2 is required for ductal morphogenesis of the mammary gland. Proc Natl Acad Sci 101: $17138-17143$.

Jenkins G. 2008. The role of proteases in transforming growth factor-beta activation. Int $\mathrm{J}$ Biochem Cell Biol 40: $1068-1078$.

Joshi PA, Jackson HW, Beristain AG, Di Grappa MA, Mote PA, Clarke CL, Stingl J, Waterhouse PD, Khokha R. 2010. Progesterone induces adult mammary stem cell expansion. Nature 465: 803-807.

Kamalati T, Niranjan B, Yant J, Buluwela L. 1999. HGF/SF in mammary epithelial growth and morphogenesis: In vitro and in vivo models. J Mammary Gland Biol Neoplasia 4: 69-77.

Kassiri Z, Defamie V, Hariri M, Oudit GY, Anthwal S, Dawood F, Liu P, Khokha R. 2009. Simultaneous transforming growth factor $\beta$-tumor necrosis factor activation and cross-talk cause aberrant remodeling response and myocardial fibrosis in Timp3-deficient heart. J Biol Chem 284: 29893-29904.

Keely PJ, Wu JE, Santoro SA. 1995. The spatial and temporal expression of the $\alpha 2 \beta 1$ integrin and its ligands, collagen I, collagen IV, and laminin, suggest important roles in mouse mammary morphogenesis. Differentiation 59: $1-13$.

Kelsey JL, Gammon MD, John EM. 1993. Reproductive factors and breast cancer. Epidemiol Rev 15: 36-47.

Kessenbrock K, Plaks V, Werb Z. 2010. Matrix metalloproteinases: Regulators of the tumor microenvironment. Cell 141: 52-67.

Kleinberg DL, Feldman M, Ruan W. 2000. IGF-I: An essential factor in terminal end bud formation and ductal morphogenesis. J Mammary Gland Biol Neoplasia 5: 7-17.

Kouros-Mehr H, Slorach EM, Sternlicht MD, Werb Z. 2006. GATA-3 maintains the differentiation of the luminal cell fate in the mammary gland. Cell 127: 1041-1055.

Lanigan F, O'Connor D, Martin F, Gallagher WM. 2007. Molecular links between mammary gland development and breast cancer. Cell Mol Life Sci 64: 3159-3184.
Lee EY, Parry G, Bissell MJ. 1984. Modulation of secreted proteins of mouse mammary epithelial cells by the collagenous substrata. J Cell Biol 98: 146-155.

Lilla JN, Joshi RV, Craik CS, Werb Z. 2009. Active plasma kallikrein localizes to mast cells and regulates epithelial cell apoptosis, adipocyte differentiation, and stromal remodeling during mammary gland involution. J Biol Chem 284: 13792-13803.

Liu S, Ginestier C, Charafe-Jauffret E, Foco H, Kleer CG, Merajver SD, Dontu G, Wicha MS. 2008. BRCA1 regulates human mammary stem/progenitor cell fate. Proc Natl Acad Sci 105: 1680-1685.

Lu P, Werb Z. 2008. Patterning mechanisms of branched organs. Science 322: 1506-1509.

Lu P, Sternlicht MD, Werb Z. 2006. Comparative mechanisms of branching morphogenesis in diverse systems. J Mammary Gland Biol Neoplasia 11: 213-228.

Lu P, Ewald AJ, Martin GR, Werb Z. 2008. Genetic mosaic analysis reveals FGF receptor 2 function in terminal end buds during mammary gland branching morphogenesis. Dev Biol 321: 77-87.

Luetteke NC, Qiu TH, Fenton SE, Troyer KL, Riedel RF, Chang A, Lee DC. 1999. Targeted inactivation of the EGF and amphiregulin genes reveals distinct roles for EGF receptor ligands in mouse mammary gland development. Development 126: 2739-2750.

Lund LR, Bjorn SF, Sternlicht MS, Nielsen BS, Solberg H, Usher PA, Osterby R, Christensen IJ, Stephens RW, Bugge $\mathrm{TH}$, et al. 2000. Lactational competence and involution of the mouse mammary gland require plasminogen. Development 127: 4481-4492.

Lund LR, Romer J, Thomasset N, Solberg H, Pyke C, Bissell MJ, Dano K, Werb Z. 1996. Two distinct phases of apoptosis in mammary gland involution: Proteinase-independent and -dependent pathways. Development 122: 181-193.

Mallepell S, Krust A, Chambon P, Brisken C. 2006. Paracrine signaling through the epithelial estrogen receptor $\alpha$ is required for proliferation and morphogenesis in the mammary gland. Proc Natl Acad Sci 103: 2196-2201.

Martin DC, Fowlkes JL, Babic B, Khokha R. 1999. Insulinlike growth factor II signaling in neoplastic proliferation is blocked by transgenic expression of the metalloproteinase inhibitor TIMP-1. J Cell Biol 146: 881-892.

McClellan HL, Miller SJ, Hartmann PE. 2008. Evolution of lactation: Nutrition v. protection with special reference to five mammalian species. Nutr Res Rev 21: 97-116.

Mohammed FF, Khokha R. 2005. Thinking outside the cell: Proteases regulate hepatocyte division. Trends Cell Biol 15: 555-563.

Mohammed FF, Pennington CJ, Kassiri Z, Rubin JS, Soloway PD, Ruther U, Edwards DR, Khokha R. 2005. Metalloproteinase inhibitor TIMP-1 affects hepatocyte cell cycle via HGF activation in murine liver regeneration. Hepatology 41: 857-867.

Mohammed FF, Smookler DS, Taylor SE, Fingleton B, Kassiri Z, Sanchez OH, English JL, Matrisian LM, Au B, Yeh WC, et al. 2004. Abnormal TNF activity in Timp3-/mice leads to chronic hepatic inflammation and failure of liver regeneration. Nat Genet 36: 969-977. 
R. Khokha and Z. Werb

Monks J, Smith-Steinhart C, Kruk ER, Fadok VA, Henson PM. 2008. Epithelial cells remove apoptotic epithelial cells during post-lactation involution of the mouse mammary gland. Biol Reprod 78: 586-594.

Mori H, Gjorevski N, Inman JL, Bissell MJ, Nelson CM. 2009. Self-organization of engineered epithelial tubules by differential cellular motility. Proc Natl Acad Sci 106: $14890-14895$.

Murphy G. 2008. The ADAMs: Signalling scissors in the tumour microenvironment. Nat Rev Cancer 8: 929-941.

Murphy G, Nagase H. 2008. Progress in matrix metalloproteinase research. Mol Aspects Med 29: 290-308.

Murphy G, Murthy A, Khokha R. 2008. Clipping, shedding and RIPping keep immunity on cue. Trends Immunol 29: $75-82$.

Murthy A, Defamie V, Smookler DS, Di Grappa MA, Horiuchi K, Federici M, Sibilia M, Blobel CP, Khokha R. 2010. Ectodomain shedding of EGFR ligands and TNFR1 dictates hepatocyte apoptosis during fulminant hepatitis in mice. J Clin Invest 120: 2731-2744.

Neville MC, McFadden TB, Forsyth I. 2002. Hormonal regulation of mammary differentiation and milk secretion. J Mammary Gland Biol Neoplasia 7: 49-66.

Noe V, Fingleton B, Jacobs K, Crawford HC, Vermeulen S, Steelant W, Bruyneel E, Matrisian LM, Mareel M. 2001. Release of an invasion promoter E-cadherin fragment by matrilysin and stromelysin-1. J Cell Sci 114: 111-118.

O'Brien J, Schedin P. 2009. Macrophages in breast cancer: Do involution macrophages account for the poor prognosis of pregnancy-associated breast cancer? J Mammary Gland Biol Neoplasia 14: 145-157.

Oakes SR, Rogers RL, Naylor MJ, Ormandy CJ. 2008. Prolactin regulation of mammary gland development. J Mammary Gland Biol Neoplasia 13: 13-28.

Oftedal OT. 2002. The mammary gland and its origin during synapsid evolution. J Mammary Gland Biol Neoplasia 7: 225-252.

Page-McCaw A, Ewald AJ, Werb Z. 2007. Matrix metalloproteinases and the regulation of tissue remodelling. Nat Rev Mol Cell Biol 8: 221-233.

Pang WW, Hartmann PE. 2007. Initiation of human lactation: Secretory differentiation and secretory activation. J Mammary Gland Biol Neoplasia 12: 211-221.

Pollard JW, Hennighausen L. 1994. Colony stimulating factor 1 is required for mammary gland development during pregnancy. Proc Natl Acad Sci 91: 9312-9316.

Radisky DC, Hartmann LC. 2009. Mammary involution and breast cancer risk: Transgenic models and clinica studies. J Mammary Gland Biol Neoplasia 14: 181-191.

Radisky DC, Hirai Y, Bissell MJ. 2003. Delivering the message: Epimorphin and mammary epithelial morphogenesis. Trends Cell Biol 13: 426-434.

Richards RG, Klotz DM, Walker MP, Diaugustine RP. 2004. Mammary gland branching morphogenesis is diminished in mice with a deficiency of insulin-like growth factor-I (IGF-I), but not in mice with a liver-specific deletion of IGF-I. Endocrinology 145: 3106-3110.

Robinson GW. 2007. Cooperation of signalling pathways in embryonic mammary gland development. Nat Rev Genet 8: $963-972$.
Robinson GW, McKnight RA, Smith GH, Hennighausen L. 1995. Mammary epithelial cells undergo secretory differentiation in cycling virgins but require pregnancy for the establishment of terminal differentiation. Development 121: 2079-2090.

Rossiter H, Barresi C, Ghannadan M, Gruber F, Mildner M, Fodinger D, Tschachler E. 2007. Inactivation of VEGF in mammary gland epithelium severely compromises mammary gland development and function. FASEB $J$ 21: 3994-4004.

Ruan W, Monaco ME, Kleinberg DL. 2005. Progesterone stimulates mammary gland ductal morphogenesis by synergizing with and enhancing insulin-like growth factor-I action. Endocrinology 146: 1170-1178.

Schedin P, Mitrenga T, McDaniel S, Kaeck M. 2004. Mammary ECM composition and function are altered by reproductive state. Mol Carcinog 41: 207-220.

Schenk S, Hintermann E, Bilban M, Koshikawa N, Hojilla C, Khokha R, Quaranta V. 2003. Binding to EGF receptor of a laminin-5 EGF-like fragment liberated during MMP-dependent mammary gland involution. J Cell Biol 161: 197-209.

Sebastian J, Richards RG, Walker MP, Wiesen JF, Werb Z, Derynck R, Hom YK, Cunha GR, DiAugustine RP. 1998. Activation and function of the epidermal growth factor receptor and erbB-2 during mammary gland morphogenesis. Cell Growth Differ 9: 777-785.

Serra R, Crowley MR. 2005. Mouse models of transforming growth factor $\beta$ impact in breast development and cancer. Endocr Relat Cancer 12: 749-760.

Shackleton M, Vaillant F, Simpson KJ, Stingl J, Smyth GK, Asselin-Labat ML, Wu L, Lindeman GJ, Visvader JE. 2006. Generation of a functional mammary gland from a single stem cell. Nature 439: 84-88.

Simian M, Bissell MJ, Barcellos-Hoff MH, Shyamala G. 2009. Estrogen and progesterone receptors have distinct roles in the establishment of the hyperplastic phenotype in PR-A transgenic mice. Breast Cancer Res 11: R72.

Smookler DS, Mohammed FF, Kassiri Z, Duncan GS, Mak TW, Khokha R. 2006. Tissue inhibitor of metalloproteinase 3 regulates TNF-dependent systemic inflammation. J Immunol 176: 721-725.

Sorrell DA, Szymanowska M, Boutinaud M, Robinson C, Clarkson RW, Stein T, Flint DJ, Kolb AF. 2005. Regulation of genes encoding proteolytic enzymes during mammary gland development. J Dairy Res 72: 433-441.

Srinivasan K, Strickland P, Valdes A, Shin GC, Hinck L. 2003. Netrin-1/neogenin interaction stabilizes multipotent progenitor cap cells during mammary gland morphogenesis. Dev Cell 4: 371-382.

Stein T, Morris JS, Davies CR, Weber-Hall SJ, Duffy MA, Heath VJ, Bell AK, Ferrier RK, Sandilands GP, Gusterson BA. 2004. Involution of the mouse mammary gland is associated with an immune cascade and an acute-phase response, involving LBP, CD14 and STAT3. Breast Cancer Res 6: R75-R91.

Sternlicht MD. 2006. Key stages in mammary gland development: The cues that regulate ductal branching morphogenesis. Breast Cancer Res 8: 201.

Sternlicht MD, Kouros-Mehr H, Lu P, Werb Z. 2006. Hormonal and local control of mammary branching morphogenesis. Differentiation 74: 365-381. 
Sternlicht MD, Lochter A, Sympson CJ, Huey B, Rougier JP, Gray JW, Pinkel D, Bissell MJ, Werb Z. 1999. The stromal proteinase MMP3/stromelysin-1 promotes mammary carcinogenesis. Cell 98: 137-146.

Sternlicht MD, Sunnarborg SW, Kouros-Mehr H, Yu Y, Lee DC, Werb Z. 2005. Mammary ductal morphogenesis requires paracrine activation of stromal EGFR via ADAM17-dependent shedding of epithelial amphiregulin. Development 132: 3923-3933.

Stingl J, Raouf A, Emerman JT, Eaves CJ. 2005. Epithelial progenitors in the normal human mammary gland. J Mammary Gland Biol Neoplasia 10: 49-59.

Stingl J, Eirew P, Ricketson I, Shackleton M, Vaillant F, Cho D, Li HI, Eaves CJ. 2006a. Purification and unique properties of mammary epithelial stem cells. Nature 439: 993-997.

Stingl J, Raouf A, Eirew P, Eaves CJ. 2006b. Deciphering the mammary epithelial cell hierarchy. Cell Cycle 5: 1519-1522.

Talhouk RS, Bissell MJ, Werb Z. 1992. Coordinated expression of extracellular matrix-degrading proteinases and their inhibitors regulates mammary epithelial function during involution. J Cell Biol 118: 1271-1282.

Talhouk RS, Chin JR, Unemori EN, Werb Z, Bissell MJ 1991. Proteinases of the mammary gland: developmental regulation in vivo and vectorial secretion in culture. Development 112: 439-449.

Tidcombe H, Jackson-Fisher A, Mathers K, Stern DF, Gassmann M, Golding JP. 2003. Neural and mammary gland defects in ErbB4 knockout mice genetically rescued from embryonic lethality. Proc Natl Acad Sci 100: 8281-8286.

Turashvili G, Bouchal J, Burkadze G, Kolar Z. 2006. Wnt signaling pathway in mammary gland development and carcinogenesis. Pathobiology 73: 213-223.

Ursin G, Parisky YR, Pike MC, Spicer DV. 2001. Mammographic density changes during the menstrual cycle. Cancer Epidemiol Biomarkers Prev 10: 141-142.

Veronesi U, Boyle P, Goldhirsch A, Orecchia R, Viale G. 2005. Breast cancer. Lancet 365: 1727-1741.

Vorbach C, Capecchi MR, Penninger JM. 2006. Evolution of the mammary gland from the innate immune system? Bioessays 28: 606-616.
Walker NI, Bennett RE, Kerr JF. 1989. Cell death by apoptosis during involution of the lactating breast in mice and rats. Am J Anat 185: 19-32.

Watson CJ. 2006. Involution: apoptosis and tissue remodelling that convert the mammary gland from milk factory to a quiescent organ. Breast Cancer Res 8: 203.

Watson CJ, Khaled WT. 2008. Mammary development in the embryo and adult: A journey of morphogenesis and commitment. Development 135: 995-1003.

Weskamp G, Ford JW, Sturgill J, Martin S, Docherty AJ, Swendeman S, Broadway N, Hartmann D, Saftig P, Umland S, et al. 2006. ADAM10 is a principal 'sheddase' of the low-affinity immunoglobulin E receptor CD23. Nat Immunol 7: 1293-1298.

Widelitz RB, Veltmaat JM, Mayer JA, Foley J, Chuong CM. 2007. Mammary glands and feathers: comparing two skin appendages which help define novel classes during vertebrate evolution. Semin Cell Dev Biol 18: 255-266.

Wilkins-Port CE, Higgins PJ. 2007. Regulation of extracellular matrix remodeling following transforming growth factor- $\beta 1 /$ epidermal growth factor-stimulated epithelial-mesenchymal transition in human premalignant keratinocytes. Cells Tissues Organs 185: 116-122.

Wiseman BS, Sternlicht MD, Lund LR, Alexander CM, Mott J, Bissell MJ, Soloway P, Itohara S, Werb Z. 2003. Sitespecific inductive and inhibitory activities of MMP-2 and MMP-3 orchestrate mammary gland branching morphogenesis. J Cell Biol 162: 1123-1133.

Wiseman BS, Werb Z. 2002. Stromal effects on mammary gland development and breast cancer. Science 296: 1046-1049.

Witty JP, Wright JH, Matrisian LM. 1995. Matrix metalloproteinases are expressed during ductal and alveolar mammary morphogenesis, and misregulation of stromelysin-1 in transgenic mice induces unscheduled alveolar development. Mol Biol Cell 6: 1287-1303.

Xu R, Boudreau A, Bissell MJ. 2009. Tissue architecture and function: dynamic reciprocity via extra- and intracellular matrices. Cancer Metastasis Rev 28: 167-176.

Zarzynska J, Motyl T. 2008. Apoptosis and autophagy in involuting bovine mammary gland. J Physiol Pharmacol 59: $275-288$. 


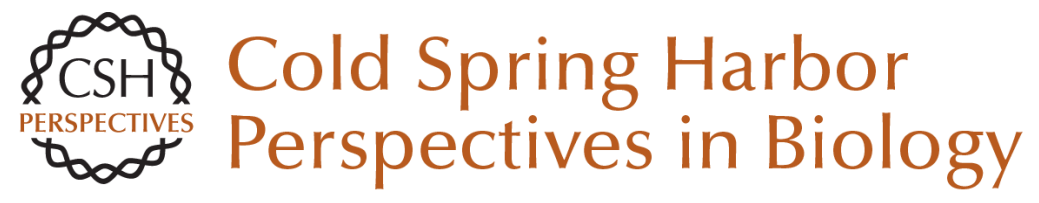

\title{
Mammary Gland Reprogramming: Metalloproteinases Couple Form with Function
}

\author{
Rama Khokha and Zena Werb
}

Cold Spring Harb Perspect Biol 2011; doi: 10.1101/cshperspect.a004333 originally published online November 24, 2010

\section{Subject Collection The Mammary Gland as an Experimental Model}

On the Role of the Microenvironment in Mammary

Gland Development and Cancer Derek Radisky

On Using Functional Genetics to Understand

Breast Cancer Biology

Kornelia Polyak

On Oncogenes and Tumor Suppressor Genes in the Mammary Gland

Rushika M. Perera and Nabeel Bardeesy

On Leukocytes in Mammary Development and Cancer

Cyrus M. Ghajar

On Chromatin Remodeling in Mammary Gland

Differentiation and Breast Tumorigenesis Kornelia Polyak

On Hormone Action in the Mammary Gland J.M. Rosen

TGF- $\beta$ Biology in Mammary Development and Breast Cancer

Harold Moses and Mary Helen Barcellos-Hoff
On How Mammary Gland Reprogramming

Metalloproteinases Couple Form with Function Bonnie F. Sloane

On Molecular Mechanisms Guiding Embryonic

Mammary Gland Development

Gertraud W. Robinson

On Stem Cells in the Human Breast Mark A. LaBarge

On Murine Mammary Epithelial Stem Cells:

Discovery, Function, and Current Status Jeffrey M. Rosen

On In Vivo Imaging in Cancer

David Piwnica-Worms

Choosing a Mouse Model: Experimental Biology in Context--The Utility and Limitations of Mouse Models of Breast Cancer Alexander D. Borowsky

Mammary Gland ECM Remodeling, Stiffness, and Mechanosignaling in Normal Development and Tumor Progression Pepper Schedin and Patricia J. Keely

For additional articles in this collection, see http://cshperspectives.cshlp.org/cgi/collection/

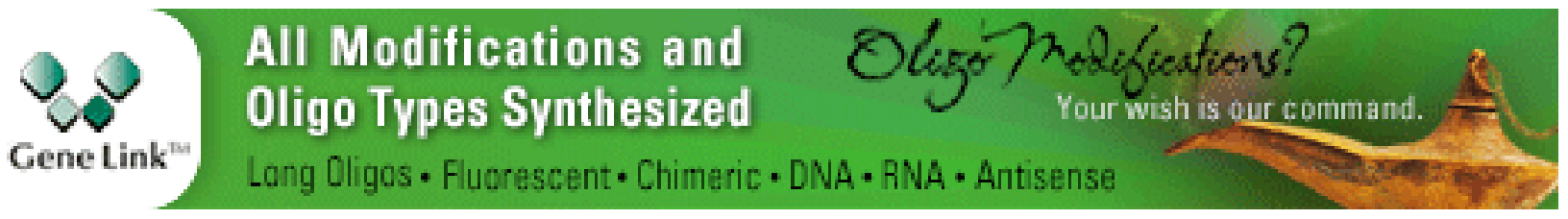


A Compendium of the Mouse Mammary Tumor Biologist: From the Initial Observations in the House Mouse to the Development of Genetically Engineered Mice

Robert D. Cardiff and Nicholas Kenney
Molecular Mechanisms Guiding Embryonic Mammary Gland Development

Pamela Cowin and John Wysolmerski

For additional articles in this collection, see http://cshperspectives.cshlp.org/cgi/collection/

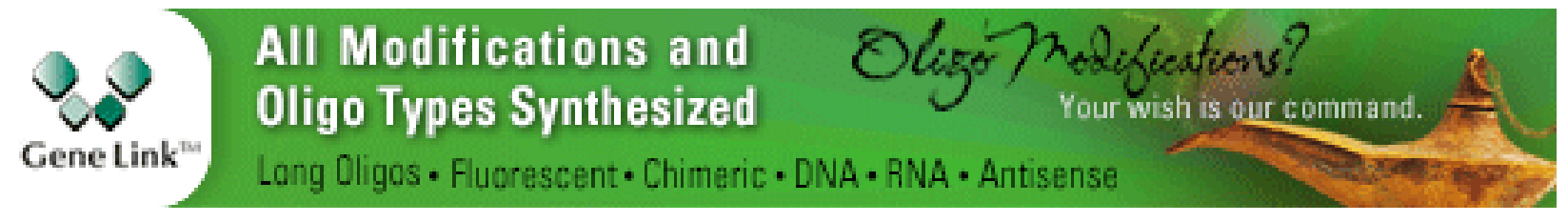

Copyright @ 2011 Cold Spring Harbor Laboratory Press; all rights reserved 